\title{
PRELIMINARY AGGLUTINATION EXPERIMENTS WITH TREPONEMA PALLIDUM*+
}

\author{
BY \\ G. EHRMANN AND H. Aa. NIELSEN \\ From the Statens Seruminstitut, Copenhagen, and the Klinik für Geschlechts- und Hautkrankheiten, Vienna
}

Nelson and Mayer (1949) demonstrated the action of immobilizing antibodies on mobile and virulent Treponema pallidum in vitro. These antibodies do not only immobilize but also destroy : treponemes exposed to such antibodies in the presence of complement lose their motility and also their virulence and their ability to multiply. However, as the first obvious manifestation of the antigen-antibody reaction was the loss of mobility of the treponemes, the reaction by which they were demonstrated was described as the Treponema pallidum Immobilization (TPI) test.

It was natural to try to demonstrate other specific antibodies against virulent Treponema pallidum. Studies of specific immobilization in vitro will reveal that many specific immobilized treponemes are not only immobile, but also appear to have changed morphologically as if they had been "chafed" or "gnawed". Frequently, there is also a visible diminution in the number of organisms. The adherence disappearance reaction developed by Nelson (1952) may be due, at least in part, to a specific lysis.

Living, mobile treponemes are known to have a tendency to form agglutinates in certain circumstances. In our experiments we have also seen that the agglutination of live treponemes may occur in the absence of antibodies in the serum. Further, we know that physical factors, such as shaking, or merely sedimentation, will agglutinate treponemes. However, Cain (1953), McLeod and Magnuson (1953), Tani and Asano (1951), and Hardy and Hollander (1953) succeeded in suspending dead treponemes in such a way that they did not agglutinate spontaneously, even after having been left for weeks at $-4^{\circ} \mathrm{C}$., or after shaking. This made it possible to repeat experiments with the same antigen and to make adequate tests of reproducibility. This and the independence of complement are the two great advantages of this method. However, the fact that no complement is necessary for the agglu-

\footnotetext{
* Received for publication February 4, 1955.

+ The experiments reported in this paper were carried out in Copenhagen in December, 1953, and January, 1954, during a study visit made possible by the World Health Organization.
}

tination reaction is also a drawback of agglutination tests if the results are intended for diagnostic use, because there is no satisfactory means of controlling the potential presence of non-specific agglutinating factors in the serum. If, however, a diagnosis of syphilis has been established, the consistent demonstration of agglutinins also opens up new possibilities in syphilis research.

The following investigations were inspired by such theoretical considerations and by the papers published by McLeod and Magnuson, by Cain, and by Hardy and Hollander on the Treponema pallidum Agglutination reaction (TPA) test. We wanted to compare the reproducibility, the sensitivity, and the specificity of the TPA test with those of TPI tests and of the old tests with lipoidal antigens by which the so-called reagins are demonstrated (reagin reactions).

\section{Methods and Material}

At the Statens Seruminstitut in Copenhagen we examined 194 sera, mostly human, for the presence of three groups of antibodies : immobilins, agglutinins, and reagins.

The TPI test (H. Aa. Nielsen) was carried out in its latest form as described by Nelson and Mayer (1949), the only modifications being a four-fold increase of the sodium thioglycollate content of the medium and the taking of readings after 18 and $42 \mathrm{hrs}$ ' incubation. In the latter case complement was added twice, i.e., immediately and after $24 \mathrm{hrs}$ ' incubation, the final contents of complement being the same as that employed in the 18-hr experiments.

Reagins were demonstrated by Meinicke's clarification test, Kahn's Standard test, and Mørch's complementfixation test with cardiolipin antigen (MR, KR, and C-WR-M).

For TPA tests (G. Ehrmann) as well as for TPI tests we used the pathogenic Nichols strain inoculated intratesticularly in rabbits. In order to avoid in vivo presensitization of the treponemes, the rabbits had been irradiated on the same day or the day before inoculation. Rabbits weighing about $3 \mathrm{~kg}$. were given a single universal radiation of about 1,000 r. Data: Focal distance $40 \mathrm{~cm}$. Filter : $0.5 \mathrm{Cu}, 1.0 \mathrm{Al}, 215 \mathrm{kV} 10 \mathrm{~mA}$. The thinly sliced testes with early orchitis were shaken in a 0.85 per cent. saline solution. Each testis was shaken 
in $20 \mathrm{ml}$. saline three times for $30 \mathrm{~min}$. at $+4^{\circ} \mathrm{C}$. The suspensions obtained were poured together after completion of shaking. A considerable amount of tissue debris, erythrocytes, and sperma was removed by 10 minutes' slow centrifugation. The clear suspension was then centrifuged for $60 \mathrm{~min}$. at 3,000 rotations per minute in a centrifuge of $20 \mathrm{~cm}$. radius. The sediment was washed once with saline, diluted to 10 to 15 million organisms per $\mathrm{ml}$. of saline, and killed by heating in a water bath at $56^{\circ} \mathrm{C}$. for $30 \mathrm{~min}$. Suspensions prepared in this way showed spontaneous agglutination in three batches out of twelve. The satisfactory suspensions were kept at $+4^{\circ} \mathrm{C}$. ready for use during the whole period of the experiment ( 4 weeks). During our attempts to prepare a reliable suspension we made the following observations.

The testes were carefully prepared and were freed from fat, because fat contents will give rise to agglutinates. Such agglutinates, which may be distinguished from specific ones, may cause a loss of treponemes and impair the readings. This applies also if the preparation is shaken too fast, and if the work is performed at higher temperatures than about $4^{\circ} \mathrm{C}$. Removal of tissue particles by filtration through coarse glass filters and through filter paper was not successful.

Apparently, morphologically damaged treponemes will adhere to the glass ; this may frequently be observed when placing treponemes on slides, and will often result in a very undesirable loss of organisms-sometimes almost 100 per cent. Equally unsatisfactory results were obtained in attempts to kill the treponemes with penicillin. Thus agglutination with treponemes prepared in this manner is completely non-specific, even if the organisms retain their form better than when they are killed by heating.

It was found that the addition of merthiolate, as recommended by Hardy and Hollander (1953) was not necessary for the preservation of the treponemes. Finally, it was observed that several treponemal suspensions did not show any in vivo sensitization in the TPI test in spite of the fact that they did agglutinate spontaneously.

Technique.-Normal agglutinins were removed from human sera by means of sheep cells. Inactivated serum $1 \mathrm{ml}$. and $2 \mathrm{ml}$. 50 per cent. sheep cell suspension in saline were thoroughly mixed and left in a water bath at $37^{\circ} \mathrm{C}$. for $90 \mathrm{~min}$. and then placed in an icebox for $18 \mathrm{hrs}$ at about $+4^{\circ} \mathrm{C}$. The sheep cells were subsequently removed by centrifugation.

Absorbed serum $0.025 \mathrm{ml}$. + antigen suspension $0.1 \mathrm{ml}$. were shaken for 2 hrs in a covered Kahn shaker, causing a rise in temperature of 28 to $30^{\circ} \mathrm{C}$. The mixture was left in a water bath at $45^{\circ} \mathrm{C}$. for 8 to $12 \mathrm{hrs}$. Antigen suspensions alone, without serum, were always used as controls.

Readings.-Without previous shaking, $0.01 \mathrm{ml}$. of the sediment was removed with a special pipette and examined in dark field. The agglutinates were first identified in low power, and then, in a higher magnification ( $\times$ 512), identified as "genuine" agglutinates. The treponemes had by then settled lengthwise end to end, forming pointed, spiral-shaped bundles of variable thickness which, by strong agglutination, again assembled into larger groups. The characteristic spiral-shaped serrations and striped appearance of the agglutinates distinguish them from the pseudo-agglutinates; in the latter agglutinates the treponemes form loose balls, mostly with an amorphous centre.

Counts were made of 25 fields ; the agglutinates thus identified were recorded in such a manner that the number of treponemes per agglutinate could be evaluated and averages calculated. At the same time, the number of free treponemes in the fields were counted. Three values were thus obtained for each serum :

(1) Number of agglutinates in 25 fields ;

(2) Average number of treponemes per agglutinate ;

(3) Number of free treponemes in 25 fields.

A positive value was defined as having at least one agglutinate with ten or more treponemes observed in each of the 25 fields. The third figure served as a control reading, the result necessarily depending upon the first two figures. The more numerous the agglutinates and the higher the average of the agglutinated treponemes. the fewer were the free treponemes and vice versa.

In this manner 154 human and forty rabbit sera were examined; the results were compared with those obtained by the reagin reactions and TPI tests.

Of these, fifty (three rabbit and 47 human sera) were taken from the stock of lyophilized sera kept at the Statens Seruminstitut in its capacity of WHO Reference Laboratory; the remaining 107 human sera were taken from the TPI routine, and the remaining 37 rabbit sera originated from various experiments set up for other purposes.

\section{Results}

(A) Human Sera.-The sera were divided into four clinical groups.

Group 1.-43 sera from 37 patients with definite anamnestic and clinical syphilis; all the patients of this group had been treated, several of them for many years.

Group 2.-Fourteen sera from fourteen patients with doubtful syphilis. Most of the patients from this group had been treated. As the results for Groups 1 and 2 were very much alike, they were compiled together (Table I).

\section{TABLE I}

GROUPS 1 AND 2: DEFINITE AND DOUBTFUL SYPHILITICS (57 SERA FROM 51 PATIENTS)

\begin{tabular}{c|c|c|c|c}
\hline $\begin{array}{c}\text { Combined } \\
\begin{array}{c}\text { Result of } \\
\text { Reagin } \\
\text { Reactions }\end{array}\end{array}$ & $\begin{array}{c}\text { Reagin } \\
\text { Reactions }\end{array}$ & \multicolumn{2}{|c|}{ TPI } & TPA \\
\cline { 3 - 5 }+ and \pm & 39 & 41 & $42 \mathrm{hrs}$ & \\
\hline- & 18 & 16 & 14 & 41 \\
\hline
\end{tabular}

Group 3.-35 sera from 34 patients in whom the possibility of syphilis could be excluded with almost 
TABLE II

TWELVE CASES WITH DISCREPANT RESULTS

\begin{tabular}{|c|c|c|c|c|c|c|c|}
\hline $\begin{array}{l}\text { Case } \\
\text { No. }\end{array}$ & $\begin{array}{c}\text { Combined } \\
\text { Result of } \\
\text { Reagin } \\
\text { Reactions }\end{array}$ & $\mathbf{T P I}_{18}$ & $\mathrm{TPI}_{42}$ & Clinical Findings & TPA & $\begin{array}{l}\text { Time of } \\
\text { Diagnosis }\end{array}$ & $\begin{array}{l}\text { Whether } \\
\text { Treated }\end{array}$ \\
\hline 1 & - & - & - & Dark field positive, primary syphilis & + & 1948 & Yes \\
\hline 2 & - & + & + & Dark field positive, primary and secondary syphilis & - & 1951 & Yes \\
\hline 3 & $\doteq$ & - & - & Dark field positive, primary syphilis & + & 1 month ago & Yes \\
\hline 4 & - & + & + & Dark field positive, secondary syphilis & $\div$ & 6 months ago & Yes \\
\hline 5 & $=$ & + & + & Aortitis & - & 1939 & Yes \\
\hline 6 & - & + & + & No information on stage of disease & - & About 1924 & Yes \\
\hline 7 & - & + & + & " $, \quad, \quad, \quad$, & + & 1918 & Yes \\
\hline 8 & - & + & + & " & + & 1947 & Yes \\
\hline 9 & $=$ & - & $=$ & " $\quad, \quad, \quad, \quad$, & - & 1952 & Yes \\
\hline 10 & $\div$ & - & - & $\begin{array}{l}\text { Doubtful congenital syphilis. Observed for non-specific } \\
\text { reactions }\end{array}$ & + & 1947 & Yes \\
\hline 11 & + & + & + & Doubtful secondary case & - & 1949 & Yes \\
\hline 12 & - & - & $\therefore$ & $\begin{array}{l}\text { "Herpes genitalis." Reagin tests strongly positive at } \\
\text { diagnosis }\end{array}$ & - & 1950 & No \\
\hline
\end{tabular}

complete certainty. In this group only a few patients had been treated.

Group 4.-Control group comprising 62 sera from healthy blood donors.

The results of the three reagin reactions C-WR-M, $K R$, and MR are listed as " combined results": + , 土, and - in Tables I, II, and III, taking the degree of conformity between the reactions and the strength of the reactions into consideration. In other words, a \pm result may signify the result of three weak reactions or of two strongly positive reactions and one negative reaction.

The summarized results given in Table I show that the three types of reactions (reagin reactions, TPI, and TPA) seem to agree fairly well. There were, in fact, twelve sera from twelve treated patients in whom discrepant results were found. These findings are given in Table II.

In presumably non-specific cases (Group 3) both TPA and TPI showed significantly fewer positive $(+$ and \pm$)$ reactions than the reagin tests $(P<1 \%)$.

\section{TABLE III}

GROUP 3: NON-SPECIFIC CASES? (35 SERA FROM 34 PATIENTS)

\begin{tabular}{|c|c|c|c|c|}
\hline \multirow{2}{*}{$\begin{array}{l}\text { Combined } \\
\text { Result of } \\
\text { Reagin } \\
\text { Reactions }\end{array}$} & \multirow{2}{*}{$\begin{array}{c}\text { Reagin } \\
\text { Reactions }\end{array}$} & \multicolumn{2}{|c|}{ TPI } & \multirow{2}{*}{ TPA } \\
\hline & & $18 \mathrm{hrs}$ & $42 \mathrm{hrs}$ & \\
\hline+ and $\doteq$ & 30 & 8 & 8 & 13 \\
\hline - & 5 & 27 & 27 & 22 \\
\hline
\end{tabular}

Results of the five positive cases in TPA, which were not positive in TPI, are listed in Table IV.

No significant difference could be demonstrated between the TPI and TPA tests.

In the controls (Group 4) the TPI and TPA reactions were negative in all sera, whereas three sera reacted in one or more of the reagin tests.

$\begin{array}{cccc}\text { (1) } & \text { C-WR-M } & \text { KR } & \text { MR } \\ \text { (2) } & - & \text { Non-readable } & \pm \\ \text { (3) } & - & \text { Non-readable } & +\end{array}$

(B) Rabbit Sera.-Sera from normal rabbits as well as from rabbits inoculated intratesticularly with the pathogenic Nichols strain of Treponema pallida were tested. Sera from rabbits immunized

TABLE IV

TPA POSITIVE, TPI NEGATIVE SERA

\begin{tabular}{|c|c|c|c|c|c|}
\hline \multirow{2}{*}{$\begin{array}{l}\text { Case } \\
\text { No. }\end{array}$} & \multirow{2}{*}{ Symptoms } & \multicolumn{3}{|c|}{ Test } & \multirow{2}{*}{$\begin{array}{l}\text { Com- } \\
\text { bined } \\
\text { Result }\end{array}$} \\
\hline & & $\overline{\mathbf{C}-\mathbf{W R}-\mathbf{M}^{*}}$ & $\mathbf{K R}^{*}$ & MR* $^{*}$ & \\
\hline 1 & Retinopathy, hyper- & - & 1 & - & \pm \\
\hline 2 & Lupus erythematosus & 11 & 8 & ++ & + \\
\hline & $\begin{array}{l}\text { orum pudendi } \\
\text { Lesion healed up in } \\
2 \text { days after local } \\
\text { treatment with mer- } \\
\text { curochrome. No glan- } \\
\text { dular swelling. No } \\
\text { induration }\end{array}$ & - & - & - & - \\
\hline 4 & Rheumatoid arthritis & 1 & 2 & $+\div$ & + \\
\hline & pulmonary infiltration & 1 & 2 & ++ & + \\
\hline
\end{tabular}

*The results of C-WR-M and KR are given in degrees of strength (Schmidt, 1951). The MR results are listed in the usual way: strongly positive $(++)$, weakly positive $(+)$, doubtful $( \pm)$, and negative $(-)$ 
TABLE V

RESULTS OF RABBIT SERUM TESTED BY TP1 BEFORE (SERUM NO. 1) AND AFTER (SERUM NO. 2) INOCULATION WITH T. PALLIDA

\begin{tabular}{|c|c|c|c|c|c|c|c|c|c|c|}
\hline Rabbit No. & Serum & TPI $_{18}$ & $\mathrm{TPI}_{42}$ & TPA & C-WR-M & $\mathbf{K R}$ & MR & $\begin{array}{l}\text { Combined } \\
\text { Result }\end{array}$ & $\begin{array}{c}\text { Time in } \\
\text { Days from } \\
\text { Inoculation }\end{array}$ & $X$ ray \\
\hline 8255 & $\begin{array}{l}1^{*} \\
2^{*}\end{array}$ & $\overline{-}$ & - & $\bar{t}$ & $\overline{4}$ & $\overline{1}$ & $\overline{+}$ & $\bar{t}$ & 13 & $1000 \mathrm{r}$ \\
\hline 8256 & $\begin{array}{l}1 \\
2\end{array}$ & $\bar{t}$ & $\overline{+}$ & $\overline{+}$ & $\overline{15}$ & $\overline{12}$ & + & $\bar{t}$ & 15 & $1000 r$ \\
\hline 8310 & $\begin{array}{l}1 \\
2\end{array}$ & $\overline{-}$ & $\overline{1}$ & $\overline{+}$ & $\overrightarrow{10}$ & $\overline{9}$ & + & $\overline{+}$ & 9 & - \\
\hline 8311 & $\begin{array}{l}1 \\
2\end{array}$ & - & - & $\overline{+}$ & - & -1 & $\overline{ \pm}$ & $\overline{ \pm}$ & 8 & - \\
\hline 8312 & $\begin{array}{l}1 \\
2\end{array}$ & - & - & - & - & - & $\overline{-}$ & - & 6 & $1000 \mathrm{r}$ \\
\hline 8314 & $\begin{array}{l}1 \\
2\end{array}$ & $\overline{-}$ & - & $\overline{+}$ & $\overline{7}$ & $\overline{5}$ & $\stackrel{ \pm}{+t}$ & $\frac{1}{t}$ & 8 & - \\
\hline 8318 & $\begin{array}{l}1 \\
2\end{array}$ & $\overline{-}$ & $\overline{-}$ & $\overline{+}$ & $\overline{5}$ & $\overrightarrow{1}$ & $+\frac{1}{+}$ & $\begin{array}{l} \pm \\
+\end{array}$ & 6 & - \\
\hline 8319 & $\begin{array}{l}1 \\
2\end{array}$ & $\overline{-}$ & $\overline{-}$ & - & $\overline{4}$ & $\overline{3}$ & \pm & $\frac{ \pm}{+}$ & 7 & - \\
\hline
\end{tabular}

* Serum No. 1 withdrawn before inoculation, Serum No. 2 from 6 to 15 days after inoculation.

against various bacterial diseases were also included in the experiments.

(1) Three pools of serum from apparently healthy rabbits with weakly positive reagin reactions were negative in both TPI and TPA tests.

One pool from thirty rabbits infected 4 months previously (WHO TPI Control No. 2) was positive in all three types of reactions.

(2) Serum was tested in eight rabbits from the TPI routine before (Serum No. 1) and after inoculation with Treponema pallida (Serum No. 2). The rabbits were not treated. The results of the three types of reaction, time from inoculation, and information on $x$-ray treatment are given in Table $\mathrm{V}$.

All No. 1 sera (except three with doubtful reagin tests) were negative in all three types of reaction. TPI $_{18}$ was positive in one No. 2 serum only, and TPI $_{42}$ was positive in the same serum and doubtful in another No 2 serum.

TPA was positive in six out of the eight No. 2 sera, and the reagin tests were positive or doubtful in seven out of the eight No. 2 sera.

(3) In an experiment set up for other purposes fifteen rabbits were infected intratesticularly with syphilis on May 5, 1952. Six weeks after inoculation all except one were treated with either penicillin or trepopal. Altogether twenty sera from these fifteen rabbits were tested (Table VI). It should be noted that all the TPA and all the TPI ${ }_{42}$ results originate from one experimental day; the TPI 18 results are taken from different days. This fact accounts for the discrepancies between the results obtained for 18 and for $42 \mathrm{hrs,}$ for which the day-by-day variations of the TPI test are responsible.

(4) Nine sera from nine rabbits immunized against typhoid fever, and two sera from rabbits immunized against leptospirosis were all negative in both TPI and TPA.

\section{Discussion}

Most of the strongly positive and clearly negative sera were examined once more in the TPA test. As was to be expected, the results showed no change. This good reproducibility was also attained in the probable, non-specific, positive cases of rheumatic fever and lupus erythematosus which were examined a few times and always showed the same weak but clearly positive results.

With regard to the sensitivity of the TPA test in comparison with that of the TPI test and the reagin reactions, altogether twelve discrepancies were found in 57 human syphilitic sera (Tables I and II). In syphilitic rabbit sera a relatively large number of positive agglutination reactions were found (Tables V and VI), especially when compared with the TPI test.

The introductory remarks about the specificity of the TPA test were confirmed by our experiments (Table III). The fact that one-third of the sera can agglutinate treponemes by non-specific normal agglutinin (Turner, 1953) shows that the test may take a non-specific course. These probably nonspecific results from sera of patients suffering from rheumatoid arthritis and lupus erythematosus are due to an agglutinating factor which is already being 
TABLE VI

RESULTS OF TWENTY SERA FROM FIFTEEN RABBITS INFECTED WITH SYPHILIS ON MAY 5, 1952

\begin{tabular}{|c|c|c|c|c|c|c|c|}
\hline $\begin{array}{c}\text { Rabbit } \\
\text { No. }\end{array}$ & $\begin{array}{l}\text { Blood } \\
\text { with- } \\
\text { drawn }\end{array}$ & $\begin{array}{l}\text { Treat- } \\
\text { ment }\end{array}$ & $\mathbf{T P I}_{18}$ & $\mathrm{TPI}_{42}$ & TPA & C-WR-M & $\mathbf{K R}$ \\
\hline 156 & $\begin{array}{c}\text { Nov. 26, } \\
1952\end{array}$ & None & + & + & $\div$ & - & 3 \\
\hline 167 & $\begin{array}{c}\text { Nov. 1, } \\
1952 \\
\text { July } 24, \\
1953\end{array}$ & $\begin{array}{l}\text { Penicillin } \\
\text { Penicillin }\end{array}$ & \pm & - & $\begin{array}{l}+ \\
+\end{array}$ & - & 1 \\
\hline 168 & $\begin{array}{c}\text { July } 24, \\
1953\end{array}$ & Penicillin & - & - & + & 1 & 2 \\
\hline 170 & \begin{tabular}{|} 
Nov. 1, \\
1952 \\
July 24, \\
1953
\end{tabular} & $\begin{array}{l}\text { Penicillin } \\
\text { Penicillin }\end{array}$ & $\begin{array}{l} \pm: \\
-\end{array}$ & - & $\begin{array}{l}+ \\
+\end{array}$ & - & $\begin{array}{l}6 \\
6\end{array}$ \\
\hline 172 & $\begin{array}{c}\text { Nov. 1, } \\
1952 \\
\text { July 24, } \\
1953\end{array}$ & $\begin{array}{l}\text { Penicillin } \\
\text { Penicillin }\end{array}$ & $\begin{array}{l}- \\
-\end{array}$ & - & $\begin{array}{l}+ \\
\div\end{array}$ & - & $\begin{array}{l}1 \\
1\end{array}$ \\
\hline $\begin{array}{l}173 \\
175\end{array}$ & $\begin{array}{c}\text { July 24, } \\
1953 \\
\text { July 24, }\end{array}$ & $\begin{array}{l}\text { Penicillin } \\
\text { Penicillin }\end{array}$ & - & - & $\therefore$ & - & $\begin{array}{l}1 \\
-\end{array}$ \\
\hline 179 & $\begin{array}{c}\text { July } 24, \\
1953\end{array}$ & Penicillin & - & - & + & - & 1 \\
\hline 180 & $\begin{array}{c}\text { July 24, } \\
1953 \\
\end{array}$ & Penicillin & - & - & $\ldots$ & - & 1 \\
\hline 182 & $\begin{array}{l}\text { Nov. 24, } \\
1952 \\
\text { July 24, } \\
1953\end{array}$ & $\begin{array}{l}\text { Trepopal } \\
\text { Trepopal }\end{array}$ & $\begin{array}{l}+ \\
+ \\
+\end{array}$ & $\begin{array}{l}+ \\
-\end{array}$ & $\begin{array}{l}+ \\
+\end{array}$ & - & $\begin{array}{l}2 \\
1\end{array}$ \\
\hline $\begin{array}{l}183 \\
185\end{array}$ & $\begin{array}{c}\text { July 24, } \\
1953 \\
\text { July 24, }\end{array}$ & $\begin{array}{l}\text { Trepopal } \\
\text { Trepopal }\end{array}$ & - & $\begin{array}{l}- \\
-\end{array}$ & $\begin{array}{l}+ \\
+\end{array}$ & - & - \\
\hline 186 & $\begin{array}{c}\text { July 24, } \\
1953\end{array}$ & Trepopal & - & $\therefore$ & $\therefore$ & - & - \\
\hline 190 & $\begin{array}{c}\text { July 24, } \\
1953\end{array}$ & Trepopal & - & - & $\cdots$ & - & 1 \\
\hline 195 & $\begin{array}{c}\text { Nov. 24, } \\
1952 \\
\text { July 24, } \\
1953\end{array}$ & $\begin{array}{l}\text { Trepopal } \\
\text { Trepopal }\end{array}$ & - & + & - & $\begin{array}{r}1 \\
-\end{array}$ & $\begin{array}{r}4 \\
.2\end{array}$ \\
\hline
\end{tabular}

used for serological diagnosis of rheumatoid arthritis (Ehrmann, Ferstl, Neumayer, and Schmidt, 1952). For this reason, and because of the difficulty of obtaining definite controls for non-specific agglutinins, we shall probably have to forgo the agglutination test in its present shape as a diagnostic aid, especially as the TPI test yields good specific reactions that so far are unsurpassed. On the other hand, the TPA test may be helpful, as mentioned above, in the further research of syphilis pathology and consequently also in the prognosis and evaluation of therapy.

\section{Summary}

In 194 sera (154 human and forty rabbit) the results of a Treponema pallidum Agglutination (TPA) test, using heat-killed pathogenic treponemes, were compared with the results obtained in the Treponema pallidum Immobilization (TPI) test and in three different reagin reactions.

The material comprised definite and doubtful syphilitic sera, presumably biologically false positive sera and normal sera. This limited material did not allow any definite conclusions as to the sensitivity and specificity of the TPA test.

In presumably biologically false positive sera both TPA and TPI tests gave significantly fewer positive results than the reagin reactions. However, there was no significant difference between the TPA and the TPI tests in these sera.

In syphilitic rabbits, agglutinins appeared almost simultaneously with reagins, the TPI test being preponderantly negative. On the other hand, the TPA test remained positive longer than the TPI, the reagins lying somewhere between the agglutinins and immobilins.

Non-specific normal agglutinins may also produce agglutination which could not always be removed entirely by absorption with sheep cells. Presumably non-specific, positive TPA was obtained in rheumatoid arthritis and lupus erythematosus in spite of absorption.

Our thanks are due to Dr. Jeppe Ørskov and Dr. Alice Reyn of the Statens Seruminstitut, Copenhagen, for their kindness and understanding in our work on the agglutination reaction.

\section{REFERENCES}

Cain, R. M. (1953). Canad. J. publ. Hlth, 44, 61.

Ehrmann, G., Ferstl, A., Neumayer, A., and Schmidt, J. (1952). Wien. Z. inn. Med., 33, 81.

Hardy, P. H., and Hollander, D. H. (1953). Abstracts of Papers, Washington, D.C., April 30 and May 1.

McLeod, C. P., and Magnuson, H. J. (1953). Publ. Hlth Rep. (Wash.), 68, 747.

Nelson, R. A. (1952). Presse méd., 60, 1719.

- and Mayer, M. M. (1949). J. exp. Med., 89, 369.

Schmidt, H. (1951). British Journal of Venereal Diseases, 27, 23.

Tani, T., and Asano, O. (1951). Jap. med. J., 4, 51.

Turner, T. (1953). WHO VD/109. Unpublished. 